\title{
Contamination in newly hatched larvae of the mangrove crab Ucides cordatus and a new perspective about trace elements transport
}

Eduardo Vianna de Almeida ${ }^{1 *}$ Vinicius Tavares Kütter ${ }^{2}$ Emmanoel Vieira Silva-Filho ${ }^{3}$

${ }^{1}$ Universidade Federal do Rio de Janeiro Instituto de Biologia

Departamento de Zoologia

Centro de Ciências da Saúde

Av. Carlos Chagas Filho, n. 373

Cidade Universitária

Rio de Janeiro RJ Brasil

CEP 21941-902

${ }^{2}$ Universidade Federal do Pará Instituto de Geociências

Programa de Pós-Graduação em Geologia e Geoquímica

Av. Perimetral, $\mathrm{n}^{\circ} 1$ - Guamá,

Belém PA Brasil

CEP 66075-110

${ }^{3}$ Universidade Federal Fluminense

Instituto de Química

Programa de Pós-Graduação em Geociências (Geoquímica Ambiental)

Outeiro São João Batista s/n - Centro

Niterói RJ Brasil.

CEP 24020-141

${ }^{*}$ Corresponding author:

vianna.almeida@gmail.com

Copyright

This is an open-access article distributed under the terms of the Creative Commons Attribution License.

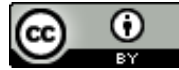

\section{RESUMO}

Manguezais são ecossistemas relevantes devido ao seu papel ecológico, uso econômico e importância social. Uma espécie abundante e importante nos manguezais brasileiros é o explotado caranguejo Ucides cordatus. Essa espécie é foco do presente estudo, cujo objetivo foi avaliar a concentração de elementos traço no hepatopâncreas de fêmeas ovígeras, em ovos (estágios de pré-eclosão e de eclosão) e, pela primeira vez, em larvas recém-eclodidas. Fêmeas ovígeras foram capturadas em dois manguezais do sudeste do Brasil (Baía de Guanabara e estuário secundário do Rio Paraíba do Sul) e desovas foram realizadas em tanques, em laboratório. Algumas fêmeas não foram levadas para os tanques, mas congeladas logo após a coleta. Não houve diferença significativa na concentração de elementos traço entre essas fêmeas e aquelas mantidas nos tanques. Elementos traço essenciais e não essenciais foram detectados nas larvas recém-eclodidas. Em comparação com a fêmea adulta, os elementos $\mathrm{Zn}$, $\mathrm{Cu}$ e $\mathrm{Mn}$ apresentaram as maiores concentrações em larvas e ovos. As concentrações de Vanádio, $\mathrm{Cr}$ e Mn foram significativamente maiores nos ovos em estágio de eclosão do que nas larvas recém-eclodidas, indicando a retenção de elementos na casca do ovo. Considerando as concentrações de V $(0,17$ $1,17 \mu \mathrm{g} . \mathrm{g}^{-1}$ peso seco), $\mathrm{Cu}\left(14,1-41,1 \mu \mathrm{g} . \mathrm{g}^{-1}\right.$ peso seco) e $\mathrm{Zn}(235,4-263,9$ $\mu \mathrm{g} \cdot \mathrm{g}^{-1}$ peso seco) em larvas recém-eclodidas, da mesma ordem de grandeza das observadas em material particulado em suspensão (MPS) e sedimentos em suspensão, a dispersão das larvas planctônicas pode resultar no transporte de elementos para além do manguezal e sua introdução em águas costeiras.

Palavras-chave: metais traço; larva de caranguejo; ovos de caranguejo; hepatopâncreas; Sudeste do Brasil

\section{ABSTRACT}

Mangroves are relevant ecosystems due to their ecological role, economic use, and social importance. One of the most abundant and important species in Brazilian mangroves is the exploited crab Ucides cordatus. This study focuses on this species and the aim was to evaluate the concentration of trace elements in the hepatopancreas of ovigerous females, eggs (pre-hatching and hatching stages), and for the first time, in newly hatched larvae. Ovigerous females were captured in two Southeastern Brazil mangroves (Guanabara Bay and Paraíba do Sul River's secondary estuary) and spawning was held in spawning tanks, in the laboratory. Some females were not taken to the tanks, but they were frozen right after collection. There was no significant difference in trace element concentration between these females and those kept in the spawning tanks. Both essential and non-essential trace elements were detected in newly hatched larvae. Comparing with the adult female, the elements $\mathrm{Zn}, \mathrm{Cu}$, and $\mathrm{Mn}$ showed the highest concentrations in larvae and eggs. Vanadium, $\mathrm{Cr}$, and $\mathrm{Mn}$ 
concentrations were significantly higher in hatching eggs than observed in newly hatched larvae, indicating the retention of elements in the eggshell. Considering the V $\left(0.17\right.$ - $1.17 \mu \mathrm{g} . \mathrm{g}^{-1}$ dry weight $), \mathrm{Cu}\left(14.1-41.1 \mu \mathrm{g} \cdot \mathrm{g}^{-1}\right.$ dry weight), and $\mathrm{Zn}$ (235.4 - $263.9 \mu \mathrm{g} . \mathrm{g}^{-1}$ dry weight) concentrations in newly hatched larvae, with the same order of magnitude observed in suspended particulate matter (SPM) and sediments in suspension, the planktonic larval dispersion could result in the transport of elements beyond the mangrove, and their introduction in coastal waters.

Keywords: trace metals; crab larvae; crab eggs; hepatopancreas; Southeastern Brazil

\section{INTRODUCTION}

Human activities have resulted in a large introduction of trace elements into the environment, and high concentrations of these elements in coastal sediments have been a great concern in recent decades (RAINBOW; FURNESS, 2018). Accumulation of these elements is more notable in low hydrodynamic environments with high deposition rates, such as lagoons, bays, and deltas. Among these environments there are the mangroves, coastal ecosystems with extensive deposition of fine sediments - which are considered geochemical barriers due to the physical retention of particles - and formation of iron plaques in trees' roots, with consequent retention of trace metals (MACHADO et al., 2005). In addition, mangroves are critical ecosystems due to their relevant ecological role, economic use, and social importance (FIELD, 1995).

Crabs are keystone species in mangroves and salt marshes, occupying different trophic levels. In these habitats, it is possible to observe diversified crab feeding habits, such as primary consumers (herbivorous, algivorous), omnivorous, predators, and detritivorous. Due to the crabs' relevance, many studies on trace element contamination have been carried out with these animals. Burrowing crabs are bioturbators that show particularly important participation in trace elements dynamics, as shown by Costa et al. (2017). These authors pointed out the significant influence of the mud crab Neohelice granulata in the environment's arsenic dynamics. Unfortunately, the trace elements studies were held mainly with adult males. Few studies have been conducted with females, and in Brazil, we can mention Silva et al. (2018) in the Amazon region. Contamination analysis in crab eggs is still rare, and we can mention studies with $N$. granulata (BELTRAME et al., 2010, SIMONETTI et al.,
2012), Callinectes sp. (LAVRADAS et al., 2014), and Ucides cordatus (ALMEIDA et al., 2016). Regarding crab larvae, there is a predominance of ecotoxicological studies (LÓPEZ-GRECO et al., 2002; FERRER et al., 2006; AMIN; COMOGLIO 2010; LYLA; KHAN, 2010). In marine species, previous studies were limited to the analysis of maternal tissues and egg contamination, whereas newly hatched larvae were rarely considered. Up to this date, no study has focused on the contamination of newly hatched larvae. When females and early stages are disregarded in contamination studies, valuable data on the relationship between contaminants and crab reproduction are lost.

Ucides cordatus, the focus species of the present study, is known as "uçá crab" or mangrove crab and is one of the main crabs in mangroves of the western South Atlantic Ocean (SAO). Due to its burrowing and detritivorous habits, this crab is considered a keystone species, playing an important role in nutrient cycling (NORDHAUS; WOLFF, 2007). Unfortunately, this crab appears on the list of endangered species, mainly due to overexploitation and frequent environmental issues in Brazilian mangroves such as deforestation, landfill, shrimp farming, and effluent disposal (PINHEIRO; RODRIGUES, 2011). The mangrove crab reproduces in the summer and females carry the egg mass in their abdominal appendages for approximately 20 days (PINHEIRO; HATTORI, 2003). Their spawning is synchronized with nocturnal ebb tides, and the species exhibits a larval export strategy (ALMEIDA et al., 2013). The U. cordatus planktonic larvae need salinities above $15 \mathrm{psu}$ (practical salinity unit) to develop successfully, so they usually need to be transported far from the adults' habitat (DIELE; SIMITH, 2006). As fertility rates are high, from $64,000.00$ up to 
220,800.00 eggs.female ${ }^{-1}$ (HATTORI; PINHEIRO, 2003), spawning periods result in a massive introduction of larvae into the pelagic environment.

During embryonic development, the $U$. cordatus egg mass remains in contact with water and sediments, being susceptible to contamination (ALMEIDA et al., 2016). The maternal transference during vitellogenesis and the absorption of mangrove pore water and minerals during embryonic development would be the main sources of trace element contamination. However, the analysis of egg mass does not clarify what percentage of the

\section{MATERIALS AND METHODS}

\subsection{STUDY SITES}

The Ucides cordatus females sampling was made in the same locations and with the same methods seen in Almeida et al. (2016). The two study sites were the Caceribu River mangrove (Guanabara Bay - GB) and the Gargaú mangrove (Paraíba do Sul River, secondary estuary - PSR), which are in SE Brazil (Fig. 1). In both areas, a humid tropical climate is predominant, with two defined seasons (wet summer and dry winter), and annual rainfall rates about 900 to $1.300 \mathrm{~mm} . \mathrm{yr}^{-1}$. The tide average amplitude in spring periods is $\pm 1.0 \mathrm{~m}$ (micro-tidal), with semidiurnal cycles. The choice of these two-collection sites was for two reasons: sampling two different populations of $U$. cordatus, and sampling environments with different degrees/types of human interference.

The Caceribu mangrove is located in the Environmental Protection Area of Guapi-Mirim, in the inner Guanabara Bay. The crabs' sampling took place at coordinates $22^{\circ} 43^{\prime} 32.55^{\prime \prime} \mathrm{S}$; $043^{\circ} 00^{\prime} 48.03^{\prime \prime} \mathrm{W}$, about two kilometers upstream from the river mouth. The Guanabara Bay is an estuarine complex with about 30 small rivers and channels and a watershed with an area of 4,080 $\mathrm{km}^{2}$ (KJERFVE et al., 1997). Fourteen cities surround the bay, with a total population of over 11 million inhabitants, being one of the highest population densities in Southeastern Brazil. The bay is also highly eutrophic and holds the secondlargest industrial park in the country, receiving massive amounts of domestic and industrial waste daily (COTOVICZ et al., 2019). Despite the degradation, the mangroves at the inner bay are contaminants remains in the eggshell (chorion) and what reaches the embryos. Thus, this study aimed to determine for the first time the trace elements concentration in $U$. cordatus newly hatched larvae from two Southeastern Brazilian mangroves (Guanabara Bay and Paraíba do Sul secondary estuary). The study also aimed to evaluate the contamination in the females' hepatopancreas, and in eggs in pre-hatching and hatching stages, in comparison with the larvae. Finally, the study discusses the relevance of planktonic larvae in the trace elements transport beyond the mangrove geochemical barrier.

relatively conserved, especially the ones located in conservation units, which add up to $80 \mathrm{~km}^{2}$.

Contamination by trace elements in the sediments of Guanabara Bay has increased significantly in the last century (MONTEIRO et al., 2012). Soares-Gomes et al. (2016), in their overview of the bay, stated that the introduction of anthropogenic origin-heavy metals and their accumulation in sediments have been evidenced by several studies. The western portion of the bay and the harbor areas are the most eutrophic and most contaminated by trace elements, mainly due to the contributions of urban effluents to rivers. The distribution of trace elements in the bay's sediments shows a strong relationship with the proximity of anthropic sources, particle size, and organic carbon content (MACHADO et al. 2002; BATISTA NETO et al. 2006). The remaining mangroves in the bay play an important role in retaining much of the metals and reducing their transport to the waters of the bay (MACHADO et al., 2002). It is known that a large amount of organic matter suspended in the bay affects the bioavailability of some metals. Such fact, known since the 1990s, makes the concentrations of trace elements lower in some organisms, even in areas where the contamination of the environment is greater (CARVALHO; LACERDA, 1992). Cordeiro et al. (2015) stated that $\mathrm{Zn}$ and $\mathrm{Cd}$ are the most labile metals in the bay, while $\mathrm{Cr}, \mathrm{Cu}$, $\mathrm{Ni}$, and $\mathrm{Hg}$ are the less, due to 62 to $84 \%$ of their concentration being associated with residual organic fraction in sediments. 


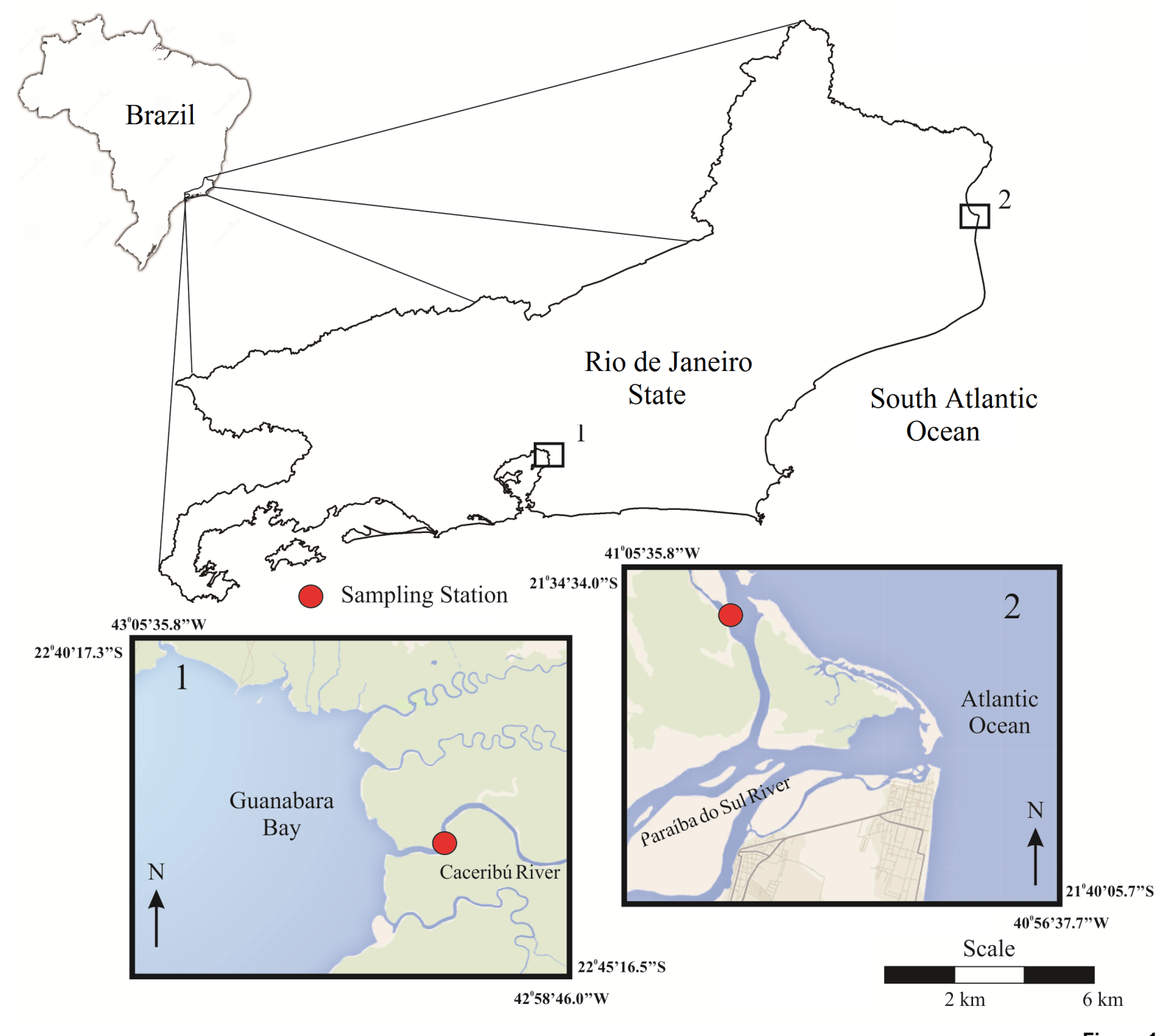

Figure 1

Location of $U$. cordatus ovigerous female sampling sites: 1. Caceribu River mangrove - Guanabara Bay (GB) and 2. Gargaú mangrove - Paraíba do Sul River (PSR), both on Southeastern Brazilian Coast, State of Rio de Janeiro. Modified from Almeida et al.

(2016).

Gargaú mangrove - the other study site - is in the secondary estuary of the Paraíba do Sul River and it is classified as moderately mesotrophic to eutrophic. The river basin comprehends three states of SE Brazil (São Paulo, Minas Gerais, and Rio de Janeiro), highly urbanized and industrialized. However, in the lower basin area, extensive agriculture prevails, especially the production of sugar cane and pineapple. Comparing this study area with the Guanabara Bay, the Gargaú mangrove region is less urbanized ( \pm 530,000 inhabitants) and the mangroves occupy an area ten times smaller $( \pm$ $8.0 \mathrm{~km}^{2}$ ). As a result of the land use, deforestation, and several dams built along this river, the volume of water has decreased in recent decades, as well as the sediments export (ANDRADE; RIBEIRO, 2020). For most of the year, the secondary Paraíba do Sul estuary is homogeneous and shows a predominance of freshwater (MOLISANI et al., 1999).

Studies showed contamination by $\mathrm{Zn}, \mathrm{Pb}$, and $\mathrm{Cu}$ in the middle course of the Paraíba do Sul River and, in general, the concentrations of these elements in the suspended particulate material and sediments have decreased towards the river mouth (CARVALHO et al.; 1999; MOLISANI et al., 1999, 2005). The exception was $\mathrm{Cr}$, which 
increased towards the estuary, probably due to its association with suspended organic matter. According to these authors, the concentrations of metals weakly bound to the sediment (fraction $<63 \mu \mathrm{m}$ ) were relatively constant throughout the river-estuary complex, except for $\mathrm{Mn}$ and $\mathrm{Fe}$, which in the estuarine region showed a decrease, probably explained by anoxic conditions. In general, the decrease in the concentration of metals downstream can be explained by the dilution in less contaminated areas or due to the barriers along the river, which generate sedimentation. However, Meneguelli-Souza et al.

\subsection{SAMPLING OF OVIGEROUS FEMALES}

To obtain newly hatched larvae, we opted to perform spawning in the laboratory. The other alternative, obtaining larvae from plankton sampling, would not allow comparing the larvae with their parents. The sample of ovigerous females occurred in three campaigns, even with the support from professional fishermen and under the license 27753-4 (Brazilian Ministry of the Environment). The first campaign was conducted in the Caceribu mangrove (GB) in January 2013. In February 2014, another campaign was assembled at the same site, and the last one took place in the Gargaú mangrove Paraíba do Sul River (PSR), by January.

In the 2013 campaign, five ovigerous females were used to obtain eggs in the prehatching stage,

\subsection{SPAWNING TANKS}

Aquarium with 38.0 liters capacity were used to obtain spawns. They were filled with water from the mangrove main channel close to the female's sample site, with salinities above 20.0 psu. Water with this salinity range was necessary to stimulate the spawn, once the species need saltwater for successful larval development (DIELE; SIMITH, 2006). Salinities both in the field and in the laboratory were evaluated using a refractometer. Before being poured into the aquariums, the water was filtered through a $64 \mu \mathrm{m}$ mesh. Trace element concentration in the aquarium water was determined with the aid of a Graphite Furnace Atomic Absorption Spectrometer (GFAAS) (Varian 240z).

Each aquarium received one female, equipped with an aerator, and kept out of the light until the spawn. The females were not fed. Check-ups were
(2021) pointed out higher concentrations of As in the sediment of the secondary estuary (our study area) and in flooded areas (5.16 \pm 4.78 and $1.23 \pm$ $0.44 \mu \mathrm{g} . \mathrm{g}^{-1}$, respectively), where the finer particle size fractions (silt and clay) prevailed. Miguens et al. (2016) studied metals by X-ray microanalysis in sediment grains from the lower basin of the PSR (including in the secondary estuary). They stated that in sediment grains, the metals occurred in at least one type of soluble compound, corroborating the pollution of the Paraíba do Sul River and the risk of contamination of the food chain.

3 to 4 days until hatching - stage VII according to Pinheiro and Hattori (2003). The eggs were transported to the laboratory and immediately frozen at $-18^{\circ} \mathrm{C}$. Another 10 females with hatching eggs ( 1 to 2 days until hatching, stage VIII) were taken to the laboratory and placed in the spawning tanks. In the 2014 campaigns, we obtained 10 females in each study area, which were transported to the spawning aquariums, and another 5 ovigerous females in each site. This last group was used to obtain hepatopancreas and eggs in the pre-hatching stage. Those females were also transported to the laboratory and frozen at $18^{\circ} \mathrm{C}$. In all cases, immediately after sampling, the animals were washed to remove the mud surplus before transportation to the laboratory.

carried out every 30 minutes and impurities were drawn from the bottom. To minimize the effects of female permanence in the aquarium, only larvae hatched in the first $24 \mathrm{~h}$ were used in the experiments. Each spawning was interrupted when $60-70 \%$ of the eggs had hatched, and the female was frozen along with the remaining eggs. This way, we obtained eggs in the hatching stage. Immediately after each spawning, the aquarium aeration was switched off. After the decantation of suspended particles, the larvae were attracted to the surface through a light stimulus. In sequence, they were carefully aspirated with the aid of sterilized pipettes. The larvae were concentrated using a sterilized $100 \mu \mathrm{m}$ opening mesh. While still attached to the mesh, they were swiftly rinsed with distilled water to remove salts. Then, an absorbent paper was placed outside the 
mesh to remove excess water. Finally, the larvae pool from each female was individually stored. Egg mass and larval pool from each female were

\subsection{TRACE ELEMENTS ANALYSIS}

All materials used in dissections, sample manipulation, and elements analysis were thoroughly acid cleaned and washed with deionized water before use. For female trace elements analysis, crabs were unfrozen, washed carefully, dried, and dissected to obtain the hepatopancreas. Pre-hatching eggs in the 2013 experiment came from the females that did not spawn, and the new larvae came from the females placed in spawning tanks. In 2014, hatching eggs and new larvae were obtained from each female of the spawning tanks. In 2014, we also obtained pre-hatching eggs from field females. In summary, five types of samples were obtained: 1 . spawning females' hepatopancreas, 2. nonspawning females' hepatopancreas, 3. eggs in pre-hatching stage, 3 . eggs in hatching stage, and 4. newly hatched larvae. individually packed and frozen at $-18^{\circ} \mathrm{C}$ until the analysis.

Each egg mass or larval pool was used as a composite sample. Eggs or larvae from different females were kept separated. Before the trace elements analysis, all samples were freeze-dried and homogenized. From each sample we derived three $0.250 \mathrm{~g}$ subsamples, that were digested in supra pure nitric acid $\left(\mathrm{HNO}_{3}\right)$, using a microwave (SpeedWave - Berghof). The trace element analysis was performed by Inductively Coupled Plasma Mass Spectrometry (ICP-MS) (Thermo Scientific ${ }^{\circledR}$ XSERIES 2). The accuracy of the analysis was evaluated by the addition of an internal standard (Rh) to all samples, and the relative error was less than $2 \%$. The accuracy of the method was checked using the SRM-1566B (oyster tissue), a certified reference material considered adequate. The detection limits of trace elements analysis methods and the recoveries are presented in Table 1.

Table 1 - Detection limits on trace elements analysis $\left(\mu \mathrm{g} \cdot \mathrm{L}^{-1}\right)$ and recovery percentages $(\%)$ in the 2013 and 2014 campaigns - Oyster Tissue Standard Reference Material (SRM 1566B). LoD: Limit of Detection ( $\left.\mu \mathrm{g} \mathrm{L}^{-1}\right)$, LoQ: Limit of Quantitation $\left(\mu \mathrm{L} \mathrm{L}^{-1}\right)$.

\begin{tabular}{ccccccc}
\hline \multirow{2}{*}{ Trace elements } & \multicolumn{2}{c}{ GFAAS } & \multicolumn{2}{c}{ ICP-MS } & \multicolumn{2}{c}{ Recovery (\%) } \\
\cline { 2 - 7 } & LoD & LoQ & LoD & LoQ & $\mathbf{2 0 1 3}$ & $\mathbf{2 0 1 4}$ \\
\hline V & 1.9 & 6.3 & $5 \times 10^{-4}$ & 5.0 & 68.8 & 72.3 \\
Cr & - & - & $6 \times 10^{-3}$ & 5.0 & - & - \\
Mn & 0.091 & 0.30 & $1 \times 10^{-3}$ & 5.0 & 96.1 & 94.2 \\
Ni & 0.72 & 2.4 & $5 \times 10^{-3}$ & 5.0 & 67.5 & 73.9 \\
Cu & 0.90 & 3.0 & $3 \times 10^{-3}$ & 5.0 & 97.2 & 84.7 \\
$\mathbf{Z n}$ & 6.5 & 22 & $1 \times 10^{-2}$ & 5.0 & 109.2 & 107.0 \\
As & - & - & $8 \times 10^{-3}$ & 5.0 & 106.4 & 104.4 \\
Cd & 0.033 & 0.10 & $4 \times 10^{-4}$ & 5.0 & 114.3 & 130.1 \\
Pb & 0.81 & 2.7 & $2 \times 10^{-3}$ & 5.0 & 124.3 & 127.4 \\
\hline
\end{tabular}

\subsection{BIOMETRY AND FECUNDITY}

The females' carapace width (CW) was evaluated by calipers $( \pm 1.0 \mathrm{~mm})$. Fecundity rates were estimated in 10 females from each study area (only 2014 campaign). The eggs were removed from the pleopods and dried with absorbent paper to remove the water surplus.
Then, the egg mass was weighed on an analytical balance $(0.0001 \mathrm{~g})$. The number of eggs.female ${ }^{-1}$ was estimated by sub-sampling, counting the eggs in three $0.5 \mathrm{~g}$ fractions from each egg mass, with the aid of a stereoscope (80x). 


\subsection{STATISTICAL ANALYSIS}

To assess differences in trace element concentrations, firstly we performed assumption checks on the homogeneity of variances (Levene's test) and normality (Shapiro-Wilk test). When the data did not show homogeneity and normality, non-parametric tests were performed (Mann-Whitney $\underline{\mathrm{U}}$ test). When the opposite occurred, Student's t-tests were applied. These tests were performed to assess differences in trace element concentration between: 1 . the two

\section{RESULTS AND DISCUSSION}

In the Caceribu mangrove (GB), the Ucides cordatus female's average carapace width (CW) was $69.0 \pm 3.0 \mathrm{~mm}$ in 2013 , and $70.0 \pm 5.0 \mathrm{~mm}$ in 2014. In the Gargaú mangrove (PSR) the average $\mathrm{CW}$ was $63.8 \pm 4.9 \mathrm{~mm}$. These average CWs are equivalent to adult specimens within the commercial size, according to Brazilian law. Ucides cordatus presents slow growth, with a frequency of one single ecdysis per year after reaching $\mathrm{CW}$ of $50.0 \mathrm{~mm}$. It reaches commercial size $(\mathrm{CW} \geq 60.0 \mathrm{~mm})$ at approximately three years, while the maximum asymptotic size $(\mathrm{CW}$ $80.0 \mathrm{~mm}$ ) is reached at about 10 years (Pinheiro et al. 2005).

In the Caceribu mangrove (GB), fecundity rates ranged from $53,624.0$ to $173,931.0$ $\left(118,411.0 \pm 36,624.0\right.$ eggs.female $\left.{ }^{-1}\right)$. In the Gargaú mangrove, they ranged from 66,005.0 to $149,134.0\left(110,355.0 \pm 28,070.0\right.$ eggs. female $\left.^{-1}\right)$. These values are higher than those observed in $U$. cordatus by Almeida et al. (2016) at the same locations: $39,297.0 \pm 18,783.0$ eggs.female ${ }^{-1}$ in the Caceribu mangrove and 84,804.0 $\pm 36,097.0$ eggs female ${ }^{-1}$ in the Gargaú mangrove. In other Southeastern Brazilian mangroves, Pinheiro et al. (2003) observed U. cordatus fecundity from $36,081.0$ to $250,565.0$ and, João and Pinheiro (2018) from $52,334.0$ to $212,801.0$ eggs.female1 , values like the observed in the present study. Also in SE Brazil, Hattori \& Pinheiro (2003) observed U. cordatus fertility rates ranging from 71,200 to $220,800.0$ larvae.female-1. In crabs and other decapods, variations in fecundity/fertility are expected even in nearby populations.. Bas et al. (2007) suggested changes in salinity levels, quality or quantity of benthic food sources, and productivity as co-responsible factors for the populations (GB and PSR), 2. hepatopancreas from spawning females and non-spawning females (from the same population), 3. prehatching and hatching eggs (from the same population), 4. pre-hatching eggs and newly hatched larvae (2013, only GB), and 4. hatching eggs and larvae (2014, GB and PSR). In all tests, results were considered significant at the 0.05 level. All analyses were performed using the software Jamovi (2020).

fecundity variations in subsequent years and in nearby populations of Neohelice granulata crab.

The spawning success rate from females of the Caceribu mangrove (GB) was 50\% in 2013 ( $\mathrm{n}=5$ females). In 2014, the success rate was $40 \%$ in both study sites. These success rates were like those observed by Pinheiro and Hattori (2003) $(44 \%)$, as was the occurrence of nocturnal spawning. In nature, $U$. cordatus spawns preferentially in nocturnal spring tides (CASTILHO-WESTPHAL et al., 2013). This strategy is commonly observed among mangrove crabs and related to an improvement in dispersion and larval survival (MORGAN, 1995).

There was no significant difference in the hepatopancreas' elements concentration among spawning and non-spawning females. The most concentrated elements in this organ were $\mathrm{Zn}, \mathrm{Cu}$, and Mn (Tab. 2), which was within expectations, since $\mathrm{Zn}$ and $\mathrm{Cu}$ are essential metals for crustaceans (RAINBOW, 2007), and Mn is highly abundant in the mangrove crab's main food source, the mangrove leaves. These leaves present relatively high $\mathrm{Mn}$ concentrations, which is an essential element for higher plants, including mangrove trees (MACHADO et al., 2002; KABATA-PENDIAS, 2010; PINHEIRO et al., 2012). The hepatopancreas can retain trace elements in amorphous granules and is highly related to alimentation, due to its storage function (CORRÊA-JUNIOR et al., 2000). In crustaceans, there are records of $\mathrm{Zn}, \mathrm{Cu}, \mathrm{Fe}, \mathrm{Cd}, \mathrm{Hg}$, and $\mathrm{Ag}$ retention in granules, but other ions may be also immobilized (AHEARN et al., 2004).

In eggs and newly hatched larvae, $\mathrm{Zn}, \mathrm{Cu}$ and $\mathrm{Mn}$ also showed the highest concentrations, in all campaigns and study areas (Tabs. 3 and 4). Com- 
paring pre-hatching and hatching eggs from the 2014 campaigns, $\mathrm{V}, \mathrm{Cr}$, and $\mathrm{Mn}$ concentrations were significantly higher in hatching eggs, in both study sites (Fig. 2). Almeida et al. (2016) also reported an increase in the trace elements concentration in $U$. cordatus eggs throughout development. These authors suggested the adsorption of trace elements in the eggshell, especially due to the assimilation of water and salts during embryonic development. The eggs of several crab species, including $U$. cordatus, absorb water and salts from the environment, especially during the days and hours before hatching (PANDIAN, 1967; DEVRIES; FORWARD, 1991; PETERSEN; ANGER, 1997, GIMÉNEZ; ANGER 2001; PINHEIRO; HATTORI, 2003; GARCÍA-GUERRERO; HENDRICKX, 2006). The high-water absorption rates before hatching are explained by the contribution of the water in the eggshell disruption (PANDIAN, 1970). This swift absorption of water probably increases the trace elements concentration in the eggs.

Table 2 - Average \pm standard deviation of trace elements concentrations ( $\mu \mathrm{g} . \mathrm{g}^{-1}$ dry weight) in the hepatopancreas of $U$. cordatus females from the Caceribu mangrove - Guanabara Bay (2013 and 2014) and from the Gargaú mangrove - Paraíba do Sul secondary estuary (2014), SE Brazil. The $n$ symbol represents the total number of females of each group, campaign, and study site, where: nonspawning group - ovigerous females frozen immediately after sampling; spawning group - ovigerous females transported to the spawning tanks in the laboratory.

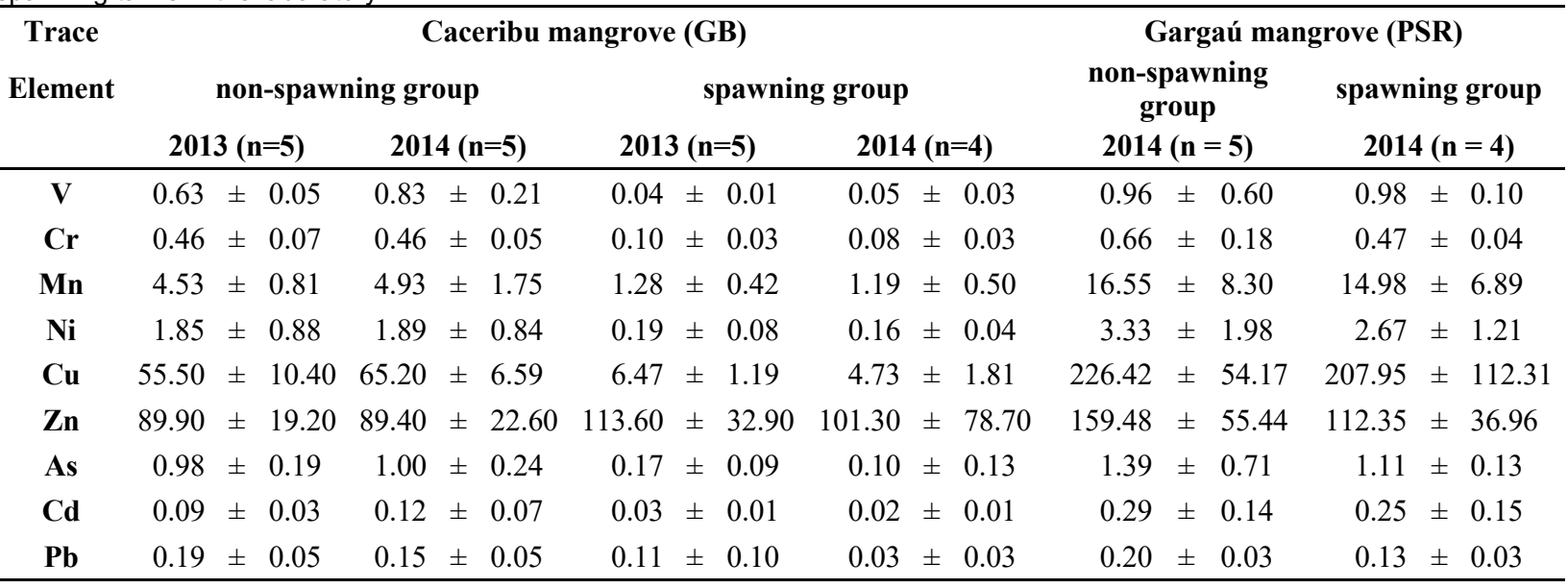

Table 3 - Average \pm standard deviation of trace elements concentrations ( $\mu \mathrm{g} \cdot \mathrm{g}^{-1}$ dry weight) in pre-hatching eggs (pre-h. eggs) and in hatching eggs of $U$. cordatus from the Caceribu mangrove - Guanabara Bay (GB - 2013 and 2014) and from the Gargaú mangrove Paraíba do Sul secondary estuary (PSR - 2014), SE Brazil. The "n" represents the total number of composite samples with eggs from each ovigerous female.

\begin{tabular}{|c|c|c|c|c|c|c|c|c|c|c|c|c|c|c|}
\hline \multirow{4}{*}{$\begin{array}{c}\text { Trace } \\
\text { Element } \\
\mathrm{V}\end{array}$} & \multicolumn{8}{|c|}{ Caceribu mangrove (GB) } & \multicolumn{6}{|c|}{ Gargau mangrove (PSR) } \\
\hline & \multirow{2}{*}{\multicolumn{2}{|c|}{$\begin{array}{l}\text { pre-h. eggs } \\
2013(\mathbf{n}=5)\end{array}$}} & \multirow{2}{*}{\multicolumn{3}{|c|}{$\begin{array}{l}\text { pre-h. eggs } \\
\mathbf{2 0 1 4}(\mathbf{n}=5)\end{array}$}} & \multirow{2}{*}{\multicolumn{3}{|c|}{$\begin{array}{l}\text { hatching eggs } \\
2014(n=5)\end{array}$}} & \multirow{2}{*}{\multicolumn{3}{|c|}{$\begin{array}{l}\text { pre-h. eggs } \\
\mathbf{2 0 1 4}(\mathbf{n}=\mathbf{5})\end{array}$}} & \multirow{2}{*}{\multicolumn{3}{|c|}{$\begin{array}{c}\text { hatching eggs } \\
2014(n=5)\end{array}$}} \\
\hline & & & & & & & & & & & & & & \\
\hline & 3.05 & \pm 3.37 & 1.57 & \pm & 1.03 & 1.57 & \pm & 0.92 & 1.21 & \pm & 1.40 & 7.82 & \pm & 1.99 \\
\hline $\mathrm{Cr}$ & 1.26 & \pm 1.11 & 0.65 & \pm & 0.41 & 0.65 & \pm & 0.37 & 0.59 & \pm & 0.58 & 1.90 & \pm & 0.47 \\
\hline Mn & 19.40 & \pm 14.40 & 5.26 & \pm & 1.03 & 5.26 & \pm & 0.92 & 4.70 & \pm & 4.24 & 18.59 & \pm & 12.57 \\
\hline $\mathbf{N i}$ & 0.71 & \pm 0.42 & 0.36 & \pm & 0.14 & 0.36 & \pm & 0.13 & 0.38 & \pm & 0.19 & 0.83 & \pm & 0.21 \\
\hline $\mathrm{Cu}$ & 23.40 & \pm 7.97 & 36.11 & \pm & 24.93 & 36.10 & \pm & 22.30 & 82.66 & \pm & 28.21 & 30.29 & \pm & 4.85 \\
\hline Zn & 221.70 & \pm 16.50 & 254.01 & \pm & 25.89 & 254.00 & \pm & 23.20 & 301.41 & \pm & 37.89 & 239.50 & \pm & 20.02 \\
\hline As & 11.80 & \pm 3.21 & 1.63 & \pm & 0.25 & 1.63 & \pm & 0.22 & 1.98 & \pm & 0.73 & 2.15 & \pm & 0.39 \\
\hline Cd & 0.01 & \pm 0.01 & 0.01 & \pm & 0.02 & 0.01 & \pm & 0.02 & 0.03 & \pm & 0.03 & 0.06 & \pm & 0.01 \\
\hline $\mathbf{P b}$ & 3.79 & $\pm \quad 3.19$ & 0.78 & \pm & 0.57 & 0.78 & \pm & 0.51 & 0.34 & \pm & 0.30 & 1.55 & \pm & 0.16 \\
\hline
\end{tabular}


Table 4 - Average \pm standard deviation of trace elements concentrations ( $\mu \mathrm{g} \cdot \mathrm{g}^{-1}$ dry weight) in newly hatched larvae of $U$. cordatus from the Caceribu mangrove - Guanabara Bay (GB - 2013 and 2014) and from the Gargaú mangrove - Paraíba do Sul secondary estuary (PSR - 2014), SE Brazil. The "n" represents the total number of composite samples made with larvae from each spawning female.

\begin{tabular}{|c|c|c|c|c|c|c|}
\hline \multirow{3}{*}{$\begin{array}{c}\begin{array}{c}\text { Trace } \\
\text { Element. }\end{array} \\
\mathrm{V}\end{array}$} & \multicolumn{3}{|c|}{ Caceribu mangrove (GB) } & \multirow{2}{*}{\multicolumn{3}{|c|}{$\begin{array}{c}\text { Gargau mangrove (PSR) } \\
2014(n=4)\end{array}$}} \\
\hline & \multicolumn{2}{|c|}{$2013(n=5)$} & $2014(n=4)$ & & & \\
\hline & 0.82 & \pm 0.18 & $1.17 \pm 0.64$ & 0.17 & \pm & 0.05 \\
\hline $\mathrm{Cr}$ & 0.40 & \pm 0.11 & $0.35 \pm 0.10$ & 0.29 & \pm & 0.03 \\
\hline Mn & 12.00 & \pm 9.99 & $19.20 \pm 2.39$ & 3.88 & \pm & 0.93 \\
\hline $\mathbf{N i}$ & 0.24 & \pm 0.06 & $0.18 \pm 0.09$ & 0.06 & \pm & 0.03 \\
\hline $\mathbf{C u}$ & 21.70 & \pm 2.00 & $14.10 \pm 2.22$ & 41.08 & \pm & 6.58 \\
\hline $\mathbf{Z n}$ & 235.40 & \pm 21.10 & $263.90 \pm 23.00$ & 263.36 & \pm & 10.31 \\
\hline As & 4.37 & \pm 0.17 & $1.84 \pm 0.40$ & 1.64 & \pm & 0.38 \\
\hline Cd & 0.01 & \pm 0.01 & $0.03 \pm 0.03$ & 0.04 & \pm & 0.01 \\
\hline $\mathbf{P b}$ & 3.68 & \pm 2.57 & $1.07 \pm 0.98$ & 0.005 & \pm & 0.01 \\
\hline
\end{tabular}

As previously mentioned, there are few studies on the trace elements concentration in crab eggs. Table 5 compares trace element concentrations in crab eggs from the present study and others, including two common species in SAO. In general, the trace element concentrations were the same order of magnitude, even among different species. The only exception was $\mathrm{Cd}$ in $N$. granulata from Bahía Blanca (Argentina), which demonstrated higher values. Cadmium concentrations in the Bahía Blanca sediments (BOTTÉ et al., 2010) are higher than those observed in the Guanabara Bay mangroves (FARIAS et al., 2007). Also, considering the hydrological differences among these locations, this pollutant may be more bioavailable in Bahía Blanca.

Comparing pre-hatching eggs and larvae from different females (GB 2013 only), the Ni and As concentrations were significantly higher in eggs. Comparing hatching eggs and larvae from the same female (2014 campaigns), V, Cr, Mn, and $\mathrm{Zn}$ concentrations were significantly higher in eggs (Fig. 1). The same happened for $\mathrm{Ni}$ and $\mathrm{Cu}$ concentrations in the Gargau mangrove. This means that the eggshell can retain part of the trace elements, partially protecting the embryo. Besides, previous studies on contaminants in crab egg masses could have overestimated the embryo's contamination. It remains unknown if other contaminants, such as organochlorines, polycyclic aromatic hydrocarbons, and others, go through the same process.

Considering the porosity of the eggshell, it is unlikely that it will completely block the passage of trace elements. Therefore, it is likely that part of the trace elements present in the newly hatched larvae comes from the environment, absorbed during the egg's development. This fact is of great concern because trace elements can be toxic to adult crabs and larvae. Duarte et al. (2017), while studying adult $U$. cordatus, observed positive and significant correlations between the number of micronucleated cells (MN\%o) and concentration of $\mathrm{Hg}$ (sediment), $\mathrm{Pb}$ (water and green leaves), and $\mathrm{Cu}$ (hepatopancreas). In other words, the mean concentration of these elements was significantly associated with $U$. cordatus crab genotoxicity. In $N$. granulata adult crabs, cadmium inhibits key metabolic enzymes, interfering with ionic regulation as well as other vital functions, and reducing the resistance against osmotic and other stresses (VITALE et al. 1999). The same physiological trends should occur with larvae. In larvae of the same species, Ferrer et al. (2006) pointed out that the toxicity of metals followed the order cadmium $>$ lead $>$ copper $>$ zinc. Rodríguez and Medesani (1994) demonstrated the occurrence of morphological abnormalities in larvae of $N$. granulata when ovigerous females are exposed to cadmium. In the crab Parasesarma pictum the larval metamorphosis delay was observed after exposition to $\mathrm{Zn}$, even in low concentrations (PASUPATHI; KANNUPANDI, 1989). In larvae of the Portunus pelagicus swimming crab, $\mathrm{Cu}, \mathrm{Ni}$, and $\mathrm{Cr}$ inhibited molting, increased development duration, and decreased average juvenile body size (MORTIMER; MILLER, 1994). Mendoza- 

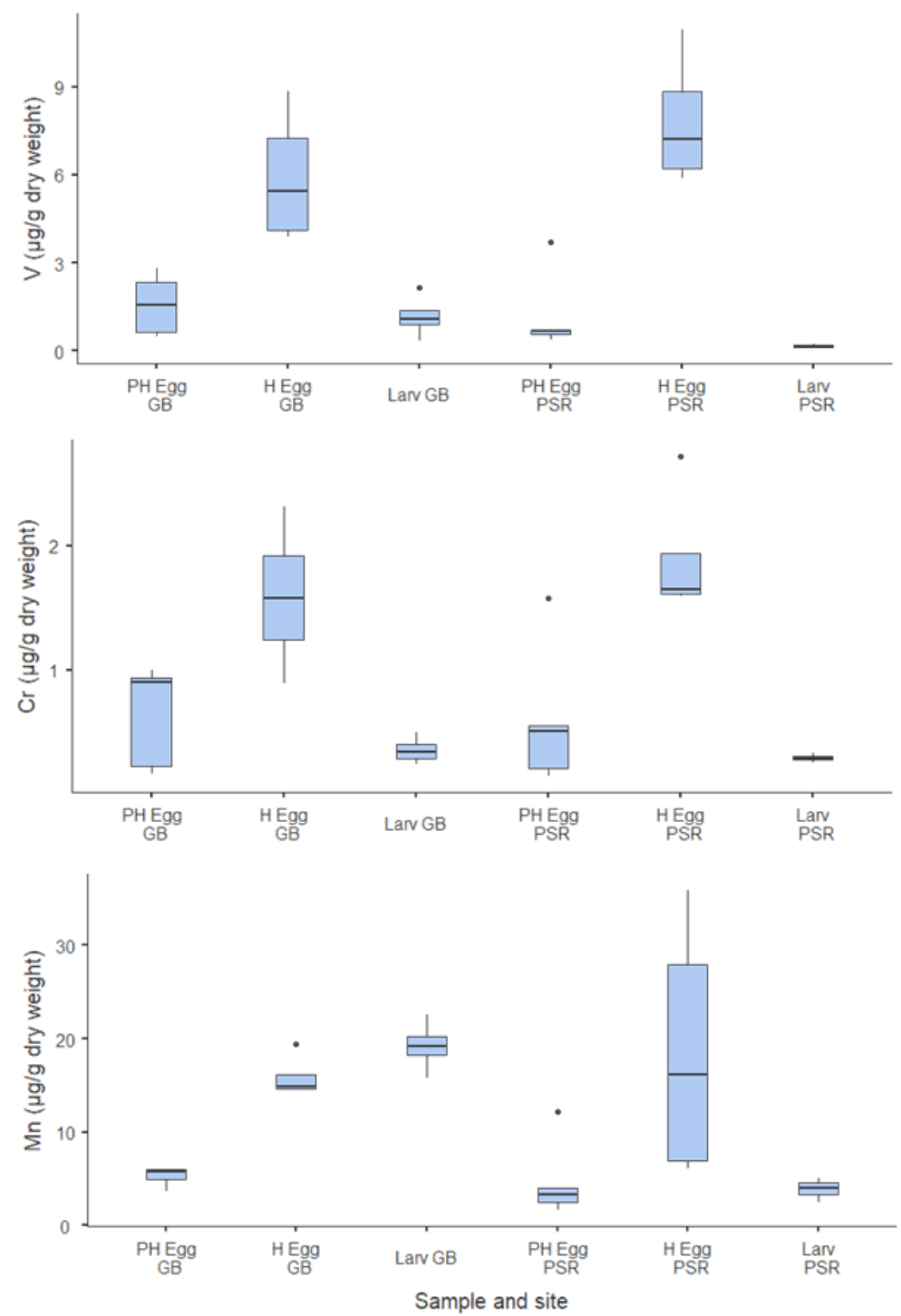

Figure 2

Box plots (showing median, quartiles, minimum-maximum and outliers) of $\mathrm{V}, \mathrm{Cr}$, and $\mathrm{Mn}$ concentrations ( $\mu \mathrm{g} . \mathrm{g}^{-1} \mathrm{dry}$ weight) in prehatching eggs (PH Egg), hatching eggs ( $\mathrm{H} \mathrm{Egg}$ ), and newly hatched larvae (Larv) of $U$. cordatus crabs (2014 campaigns) from the Caceribu River - Guanabara Bay (GB) and from the Gargau mangrove - Paraíba do Sul River (PSR), Southeastern Brazil.

Carranza et al. (2016), in one of the few published studies about trace element concentration in crab larvae, observed concentrations of $4.75 \mu \mathrm{g} \mathrm{Cr} . \mathrm{g}^{-1}$, $5.37 \mu \mathrm{g} \quad \mathrm{Ni} . \mathrm{g}^{-1}$, and $112.2 \mu \mathrm{g} \quad \mathrm{Zn}^{-g^{-1}}$ in planktivorous brachyuran larvae obtained from plankton samples in a Mexico lagoon. Although these authors did not specify the larval stage or species, $\mathrm{Cr}$ and $\mathrm{Ni}$ concentrations were 10 to 30 times higher than those observed in the present study. However, Zn concentrations were lower, about half the concentrations observed for $U$. cordatus newly hatched larvae. One of the few works about trace elements concentration in marine invertebrates newly hatched larvae is
Weng and Wang (2017). Comparing our results with that work, performed with oyster newly hatched larvae (Crassostrea hongkongensis) from two polluted estuaries in Southern China, $\mathrm{Cr}, \mathrm{Ni}$, $\mathrm{Cu}, \mathrm{As}$, and $\mathrm{Cd}$ concentrations were higher in oyster larvae (two to ten times). On the other hand, $\mathrm{Zn}$ and $\mathrm{Pb}$ (except PSR) concentrations were higher in the $U$. cordatus larvae. The difference in concentrations among species and sampling sites may reflect the larval instar or stage, environmental contamination levels (especially in the water), and trace elements bioavailability. 
Table 5 - Average trace element concentrations ( $\mu \mathrm{g} . \mathrm{g}^{-1}$ dry weight) in crab eggs from South Atlantic Ocean species. (-): not analyzed, nd: not detected.

\begin{tabular}{|c|c|c|c|c|c|c|c|c|c|}
\hline \multirow{2}{*}{ Species } & \multirow{2}{*}{ Study area } & \multirow{2}{*}{ Egg stage } & \multicolumn{6}{|c|}{ Trace elements } & \multirow{2}{*}{ References } \\
\hline & & & $\mathrm{Cr}$ & $\mathrm{Mn}$ & $\mathrm{Cu}$ & $\mathrm{Zn}$ & $\mathrm{Cd}$ & $\mathrm{Pb}$ & \\
\hline \multirow{7}{*}{$\begin{array}{l}\text { Ucides } \\
\text { cordatus }\end{array}$} & \multirow{4}{*}{$\begin{array}{c}\text { Guanabara Bay, SE } \\
\text { Brazil }\end{array}$} & pre-hatching & 1.6 & 15.8 & 27.0 & 171.0 & 0.06 & 6.1 & $\begin{array}{l}\text { ALMEIDA et al. } \\
(2016)\end{array}$ \\
\hline & & pre-hatching & 1.3 & 19.4 & 23.4 & 221.7 & 0.01 & 3.8 & $\begin{array}{c}\text { This study ( } 2013 \\
\text { campaign) }\end{array}$ \\
\hline & & pre-hatching & 0.6 & 5.3 & 36.1 & 254.0 & 0.01 & 0.8 & This study (2014 \\
\hline & & hatching eggs & 0.7 & 5.3 & 36.1 & 254.0 & 0.01 & 0.8 & campaign) \\
\hline & \multirow{3}{*}{$\begin{array}{c}\text { Paraíba do Sul River, } \\
\text { SE Brazil }\end{array}$} & pre-hatching & 2.9 & 29.0 & 25.0 & 230.0 & 0.08 & 6.6 & $\begin{array}{c}\text { ALMEIDA et al. } \\
\text { (2016) }\end{array}$ \\
\hline & & pre-hatching & 0.6 & 4.7 & 82.7 & 301.4 & 0.03 & 0.3 & This study (2014 \\
\hline & & hatching eggs & 1.9 & 18.6 & 30.3 & 239.5 & 0.06 & 1.6 & campaign) \\
\hline Callinectes sp. & Ilha Grande, SE Brazil & not informed & - & - & 44.1 & 290.2 & 0.05 & 1.4 & $\begin{array}{l}\text { LAVRADAs et al. } \\
\text { (2014) }\end{array}$ \\
\hline \multirow{4}{*}{$\begin{array}{l}\text { Neohelice } \\
\text { granulata }\end{array}$} & \multirow{2}{*}{$\begin{array}{l}\text { Mar Chiquita, } \\
\text { Argentina }\end{array}$} & $\begin{array}{c}\text { pre- } \\
\text { hatching/hatching }\end{array}$ & 1.0 & 53.8 & 53.2 & - & 0.50 & - & \multirow{2}{*}{$\begin{array}{c}\text { BELTRAME et al. } \\
(2010)\end{array}$} \\
\hline & & $\begin{array}{c}\text { pre- } \\
\text { hatching/hatching }\end{array}$ & 1.5 & 23.4 & 48.9 & - & 0.71 & - & \\
\hline & \multirow{2}{*}{$\begin{array}{c}\text { Bahía Blanca, } \\
\text { Argentina }\end{array}$} & not informed & nd & - & 62.5 & - & 6.38 & - & \multirow{2}{*}{$\begin{array}{c}\text { SIMONETTI et al. } \\
\text { (2012) }\end{array}$} \\
\hline & & not informed & nd & - & 51.3 & - & 3.76 & - & \\
\hline
\end{tabular}

In the present study, when comparing female hepatopancreas and their newly hatched larvae, some trace elements showed significantly different concentrations. In the 2013 campaign in the Caceribu mangrove (GB), the trace elements concentration was significantly higher in larvae, except for $\mathrm{Ni}$ and Cr. In 2014, at the same site, Mn and $\mathrm{Zn}$ were also significantly higher in larvae. In the Gargaú mangrove (PSR) the same pattern was observed with $\mathrm{Zn}$. The higher concentration of zinc, an essential metal for crustaceans (RAINBOW, 2007), may be associated with the maternal transfer, female depuration, or natural absorption of this metal. Lavradas et al. (2014) found higher $\mathrm{Cd}$ and $\mathrm{Zn}$ concentrations in eggs of the swimming crab Callinectes sp., when compared to the females' hepatopancreas. These authors, analyzing metallothioneins and glutathione concentrations, observed a strong correlation, which indicates the transfer of $\mathrm{Pb}$ and $\mathrm{Zn}$ from females to embryos. Regarding the higher concentration of $\mathrm{Mn}$ and other elements in $U$. cordatus larvae, it could indicate depuration of trace metals or metalloids in females. Tsui and Wang (2007) detected maternal transfer as a route for metal elimination in Daphnia magna (Crustacea: Branchiopoda), especially for Se, Zn, and $\mathrm{MeHg}$. For a better understanding of the trace elements transfer among females and embryos, an efficient method was described in Weng and Wang (2017). These authors, while analyzing trace elements transfer between female oysters and their embryos, obtained eggs directly from the gonadal tissue. In studies with crabs, this method will be considered, once would prevent the contact of the egg with the environment and the absorption or adsorption of trace elements.

Concentrations of $\mathrm{Mn}, \mathrm{Cu}$, and $\mathrm{Cd}$ were significantly higher in the females of Gargaú $(p<$ 0.005 ). In previous studies, in the same regions of the present study, these elements were more concentrated in the sediments of the PSR secondary estuary. As an example, $\mathrm{Cd}$ showed a concentration of $0.2 \mu \mathrm{g} \cdot \mathrm{g}^{-1}$ in BG mangrove sediments, west of the Caceribu River (FARIAS et al., 2007). In the PSR secondary estuary, where the Gargaú Mangrove is located, Molisani et al. (2005) recorded higher concentrations, from 0.7 to $1.8 \mu \mathrm{gCd} \cdot \mathrm{g}^{-1}$. In addition to higher concentrations in the PSR secondary estuary, probably these elements are more bioavailable in the region. Bosco-Santos et al. (2017), analyzing muscle tissue of male $U$. cordatus from Southeastern Brazil, found a positive correlation between concentrations of $\mathrm{Cu}, \mathrm{Zn}$, and $\mathrm{Pb}$ in surface sediments and crabs. These authors stressed the importance of crab feeding as a contamination pathway since there is a small but constant percentage of sediment ingestion. As previously mentioned, $\mathrm{Cu}$ is an essential metal for crustaceans and the main food of $U$. cordatus crabs is Mn-enriched. In areas with the anthropic 
introduction of these elements, it is expected that the most abundant in sediments appear in higher concentrations in crabs. Comparing GB and PSR crab eggs, there was no significant difference. On the other hand, in the newly hatched larvae from $\mathrm{GB}$, significantly higher concentrations of $\mathrm{V}, \mathrm{Mn}$, and $\mathrm{Ni}$ were observed. This could mean that either the female-embryo transfer is different between the study areas or that the conditions of sediment and pore water of the Rio Caceribu mangrove (GB) support the contamination of the embryos during the incubation of eggs. Further studies are needed to clarify these facts.

As previously stated, U. cordatus is a large mangrove crab with high fecundity rates and synchronized spawning, which exhibits a planktonic larval export strategy. This strategy enables the larvae transportation to areas with saltwater (salinity $>20 \mathrm{psu}$ ), essential for their successful development (DIELE; SIMITH, 2006). Commonly, the exportation mechanism results in larval transport to distant waters and high connectivity between populations (BRITTO et al., 2011). In the present study, we registered trace element concentrations in newly hatched larvae, including some non-essential elements. Considering the $U$. cordatus reproductive dynamics, are the planktonic larvae means of transportation of trace elements beyond mangroves? Comparing trace elements in $U$. cordatus newly hatched larvae with concentrations in suspended particulate matter (SPM) and suspended sediments, it was observed that the concentrations of $\mathrm{V}, \mathrm{Cu}, \mathrm{Zn}$, and As (only PSR) in larvae represent a significant percentage of these elements in the water column as a whole (Tab. 6). If, on the one hand, the introduction of larvae does not occur throughout the whole year, it is noteworthy that the elements present in the larvae enter much more easily in the food chain, when compared to those in the suspended sediments. Crab larvae from several species are predated by a large variety of pelagic and benthonic animals (MORGAN, 1992). Moreover, unlike the larvae, the suspended mineral materials tend to flocculate and precipitate in salinity gradients.

Table 6 - Trace elements concentration ( $\mu \mathrm{g} \cdot \mathrm{g}^{-1} \mathrm{dry}$ weight) in suspended particulate matter (SPM) from the Paraíba do Sul River (PSR), in suspended sediments from anthropized Guanabara (GB) and Sepetiba bays (SE Brazil), and in U. cordatus newly hatched larvae (present study), Southeastern Brazil.

MPS Suspended sediment Newly hatched larvae

\begin{tabular}{|c|c|c|c|c|c|c|c|}
\hline \multirow{2}{*}{$\begin{array}{c}\text { Trace } \\
\text { Element }\end{array}$} & \multicolumn{2}{|c|}{ Paraíba do Sul River } & \multirow{2}{*}{$\begin{array}{c}\text { Sepetiba bay } \\
\text { (Lacerda et al. 1988) }\end{array}$} & \multirow{2}{*}{$\begin{array}{c}\text { Guanabara bay } \\
\text { (Melo et al. 2014) }\end{array}$} & \multicolumn{2}{|c|}{ GB } & \multirow{2}{*}{$\begin{array}{l}\text { PSR } \\
2014\end{array}$} \\
\hline & $\begin{array}{c}\text { (Carvalho et al. } \\
\text { 2002) }\end{array}$ & $\begin{array}{l}\text { (Meneguelli-Souza } \\
\text { et al. 2021) }\end{array}$ & & & 2013 & 2014 & \\
\hline As & - & $1.98-2.60$ & - & - & 4.37 & 1.84 & 1.64 \\
\hline $\mathrm{V}$ & - & - & - & $\approx 0.6$ & 0.82 & 1.17 & 0.17 \\
\hline $\mathrm{Cr}$ & $47.0-79.0$ & - & $\approx 25.0-100.0$ & $\approx 200.0$ & 0.40 & 0.35 & 0.29 \\
\hline $\mathrm{Mn}$ & $1,348.0-1,913.0$ & - & $\approx 250.0-1,000.0$ & $\approx 3,000.0$ & 12.0 & 19.2 & 3.88 \\
\hline $\mathrm{Ni}$ & - & - & $\approx 20.0-60.0$ & - & 0.24 & 0.18 & 0.06 \\
\hline $\mathrm{Cu}$ & $125.0-134.0$ & - & $\approx 30.0-250.0$ & - & 21.7 & 14.1 & 41.1 \\
\hline $\mathrm{Zn}$ & $129.0-353.0$ & - & $\approx 250.0-800.0$ & $\approx 750.0-800.0$ & 235.4 & 263.9 & 263.4 \\
\hline $\mathrm{Cd}$ & - & - & $\approx 1.5-7.0$ & $\approx 10.0$ & 0.01 & 0.03 & 0.04 \\
\hline $\mathrm{Pb}$ & - & - & $\approx 30.0-130.0$ & $\approx 120.0$ & 3.68 & 1.07 & 0.005 \\
\hline
\end{tabular}

When comparing the trace element concentrations in $U$. cordatus newly hatched larvae with the Laguncularia racemosa tree leaves from the Guapimirim EPA (Guanabara Bay) (MACHADO et al. 2002), the elements Zn and $\mathrm{Cu}$ showed concentrations 18 and 2.2 times higher in the larvae. According to Ramos e Silva et al. (2006), 7\% of fallen leaves (mangrove trees) are exported to the marginal marine system in the Potengi River, NE Brazil. The average exportation rates of heavy metals through leaf litter were: $1.31(\mathrm{Zn}), 0.21(\mathrm{Cr}), 0.64(\mathrm{Cu}), 17.61$ (Ni) and $0.112(\mathrm{Cd}) \mu \mathrm{g} \cdot \mathrm{ha}^{-1}$.year ${ }^{-1}$. However, to better understand the participation of crab larvae and other organisms in the annual exportation of elements, it is necessary to go further in future 
investigations and estimate how much of the larval biomass is exported in each spawning season, for each mangrove. In addition, it will be imperative to characterize the flow and transport of the newly hatched larvae and to determine the main predators in each region, as well as the intensity of predation. To confirm the transfer in the food web will be necessary to coupling trace elements analysis with the stable isotopes study at different trophic levels, as suggested by Wang (2002).

The massive larval introduction in coastal waters during synchronized spawning generates high plankton densities. In the SE Brazilian summer, Almeida et al. (2013) registered maximum larval densities of 245.0 larvae. $\mathrm{m}^{-3}$ in the Macaé River (SE Brazil) and Almeida et al. (2017) registered 107.0 larvae. $^{-3}$ in the Guanabara Bay, although Schwamborn et al.

\section{CONCLUSIONS}

Both essential and non-essential trace elements were found in newly hatched larvae, eggs, and hepatopancreas of U. cordatus females. The elements with the highest concentrations were $\mathrm{Zn}, \mathrm{Cu}$, and $\mathrm{Mn}$. There was a higher concentration of some elements in the eggs when compared to the newly hatched larvae. This indicates the retention of part of the elements in the eggshell. Considering that the species has a larval export mechanism, the dispersion of the planktonic larvae may be responsible for the trace elements transport beyond the mangroves.

Like the $U$. cordatus, there are many other mangrove and salt marsh crab species that live in the mud, present high fecundity rates, and synchronized spawning. Examples include the crab Ucides occidentalis, various fiddler crabs

\section{ACKNOWLEDGEMENTS}

This study was partly financed by the Coordenação de Aperfeiçoamento de Pessoal de Nível Superior - Brasil (CAPES) - Finance Code 001. The authors would like to thank the Instituto Nacional de Ciência e Tecnologia (INCTTMCOcean 573601/20089), the support from the staff of the Guapimirim EPA, and the Gargaú fishermen community, especially the managers
(2001) observed higher densities (1,778.0 larvae. $\mathrm{m}^{-3}$ ) in the Itamaracá mangrove (NE Brazil). The values during synchronized spawning could be even higher. In the Caceribu River and Paraíba do Sul River, Almeida observed maximums of 332.0 and $1,892.0$ larvae. $\mathrm{m}^{-3}$, respectively (unpubl. data). It is worth mentioning that in some regions, female migration could precede spawning. We recently heard reports from Guanabara Bay fishermen regarding female migrations before spawning. The fishermen have related migrations $1.0-2.0 \mathrm{~km}$ away from the mangroves, leading to the concentration of females in muddy areas at the bottom of the bay, where the salinity is higher. If that behavior is scientifically proven, this phenomenon would indicate an increase in larval transport in the bay.

(genera Leptuca, Minuca, Uca, etc.), mud crabs such as Neohelice granulata, Goniopsis cruentata, Scylla serrata, among others. The Dotilla fenestrata and Dotilla myctiroides soldier crabs also deserve attention, due to their abundance in coastal habitats in Africa and Asia, and to their continuous reproduction throughout the year (HAILS; YAZIZ 1982; LITULO et al. 2005). All these species deserve greater attention regarding the contamination of their embryos and newly hatched larvae and on their influence on the trace elements dynamics. In future studies on trace elements and other pollutants in marine invertebrates, it is particularly important to consider female transference and the influence of water and salts absorption during the embryo's development.

and the fishermen Messrs. Alaildo Malafaia and "Jorginho" Pinheiro Machado. E. Silva-Filho is a senior researcher for the National Council for Research and Development (CNPq, Brazil) and for the Foundation for Research Support of the State of Rio de Janeiro (FAPERJ E26/203.037/2017). 
AHEARN G.A.; MANDAL P.K.; MANDAL, A. Mechanisms of heavy-metal sequestration and detoxification in crustaceans: a review. J. Comp. Physiol. B, 174(6): 439-452, 2004

ALMEIDA E.V.; BONECKER S.L.C. Fernandes L.D.A.. Exportação e retenção de decápodes planctônicos (Crustacea) no estuário do Rio Macaé (RJ) $\left(22^{\circ} 22 \mathrm{~S}-041^{\circ} 46 \mathrm{~W}\right)$. Atlântica

(Rio Grande), 35: 23-34, 2013

ALMEIDA E.V.; KÜTTER V.T.; MARQUES E.D.; SILVA-FILHO E.V. First assessment of trace metal concentration in mangrove crab eggs and other tissues, SE Brazil. Environ.

Monit. Assess., 188: 421, 2016

ALMEIDA E.V.; SANTOS J.O; SILVA G.A.; MIRANDA R.G.B. Distribuição espaçotemporal de crustáceos decápodes meroplanctônicos, com ênfase nas larvas do caranguejo-uçá, na baía de Guanabara, Rio de Janeiro. Rev CEPSUL - Biodivers. Conserv. Mar., 6: 1-19, 2017

AMIN O.A.; COMOGLIO L.I. Effects of copper on the physiological responses of the commercial crab Lithodes santolla (Decapoda: Anomura) larvae. Sci. Mar., 74(2): 215-221, 2010.

ANDRADE M.P.; RIBEIRO C.B.M. Impacts of land use and cover change on Paraíba do Sul whatershed streamflow using the SWAT model. Rev. Bras. Recurs. Hídricos, 25(12): $1-13,2020$

BAPTISTA NETO J.A.; GINGELE F.X.; LEIPE T.; BREHME I. Spatial distribution of trace elements in surficial sediments from Guanabara Bay - Rio de Janeiro/Brazil.

Environ. Geol., 49:1051-1063, 2006

BAS C.C.; SPIVAK E.D.; ANGER K. Seasonal and interpopulational variability in fertility, egg size, and elemental composition ( $\mathrm{CHN})$ of eggs and larvae in a grapsoid crab, Chasmagnathus granulatus. Helgol. Mar. Res., 61: 225-237, 2007

BELTRAME M.O.; MARCO S.G.; MARCOVECCHIO J.E. Influences of sex, habitat, and seasonality on heavy-metal concentrations in the burrowing crab (Neohelice granulata) from a coastal lagoon in Argentina. Arch. Environ. Contam. Toxicol., 58(3): 746-756, 2010

BOSCO-SANTOS A.; LUIZ-SILVA W.; SILVA-FILHO E.V.; SOUZA M.D.C.;
DANTAS E.L.; NAVARRO M.S. Fractionation of rare earth and other trace elements in crabs, Ucides cordatus, from a subtropical mangrove affected by fertilizer industry, J. Environ. Sci., 54: 69-76, 2017

BOTTÉ S.; FREIJE H.; MARCOVECCHIO J. Distribution of several heavy metals in tidal flats sediments within Bahía Blanca estuary (Argentina). Water Air Soil Pollut. Focus, 210: 371-388, 2010

BRITTO F.B.; SCHMIDT A.J.; CARVALHO A.M.F.; VASCONCELOS C.C.M.P.; FARIAS A.M.; BENTZEN P.; DINIZ F.M. Population connectivity and larval dispersal of the exploited mangrove crab along the Brazilian coast. Peer J., 6: e4702, 2018

CARVALHO C.E.V.; SALOMÃO M.S.M.B.; MOLISANI M.M.; REZENDE C.E.; LACERDA L.D. Contribution of a mediumsized tropical river to the particulate heavymetal load for the South Atlantic Ocean. Sci. Total. Environ., 284(1-3): 85-93, 2002

CARVALHO C.E.V.; LACERDA L.D. Heavy metals in the Guanabara Bay biota: Why such low concentrations? Ciência e Cultura (SBPC), 44: 184-186, 1992

CARVALHO C.E.V.; OVALLEA.R.C.; REZENDE C.E.; SALOMÃO M.S.M.B.; MOLISANI M.M.; LACERDA L.D. Seasonal variation of particulate heavy metals in the Lower Paraíba do Sul River Drainage Basin, RJ. Brazil. Environ. Geol., 37(4): 297-302, 1999

CASTILHO-WESTPHAL G.G.; OSTRENSKY A.; PIE M.R.; BOEGER W.A. Estado da arte das pesquisas com o caranguejo-uçá, Ucides cordatus. Arch. Vet. Sci., 13(2): 151-166, 2008

CORDEIRO R.C.; MACHADO W.; SANTELI R.E.; FIGUEIREDO JR. A.G.; SEOANE J.C.S.; OLIVEIRA E.P.; FREIRE A.S.; BIDONE E.D.; MONTEIRO F.F.; SILVA F.T.; MENICONI M.F.G. Geochemical fractionation of metals and semimetals in surface sediments from tropical impacted estuary (Guanabara Bay, Brazil). Envir. Earth .Sci., 74: 1363-1378, 2015

CORRÊA JUNIOR J.D.; ALLODI S.; AMADOFILHO G.M; FARINA M. Zinc accumulation in phosphate granules of Ucides cordatus 
hepatopancreas. Braz. J. Med. Biol. Res., 33(2), 217-221, 2000

COSTA L.; NICOLAI M.; GARCIA F. Arsenic environmental threshold surpass in estuarine sediments: effects of bioturbation. Bull. Environ. Contam. Toxicol., 98: 521-524, 2017

COTOVICZ JR L.; KNOPPERS B.; DEIRMENDJIAN L.; ABRIL G. Sources and sinks of dissolved inorganic carbon in an urban tropical coastal bay revealed by $\delta^{13} \mathrm{C}$-DIC signals. Estuar. Coast. Shelf. Sci., 220: 185195, 2019

DEVRIES M.C.; FORWARD JR R.B. Mechanisms of crustacean egg hatching: evidence for enzyme release by crab embryos. Mar. Biol., 110(2): 281-291, 1991

DIELE K.; SIMITH D.J.B. 2006. Salinity tolerance of northern Brazilian mangrove crab larvae, Ucides cordatus (Ocypodidae): Necessity for larval export? Estuar. Coast. Shelf. Sci., 68: 600-608

DUARTE L.F.A.; SOUZA C.A.; PEREIRA C.D.S.; PINHEIRO M.A.A. Metal toxicity assessment by sentinel species of mangroves: In situ case study integrating chemical and biomarkers analysis. Ecotoxicol. Environ. Saf., 145: 367-376, 2017

FARIAS C.O.; HAMACHER C.; WAGENER A.L.R.; CAMPOS R.C.; GODOY J.M. Trace metal contamination in mangrove sediments, Guanabara Bay, Rio de Janeiro, Brazil. J. Braz. Chem. Soc., 18(6): 1194-1206, 2007

FERRER L.; ANDRADE S.; ASTEASUAIN R.; MARCOVECCHIO J. Acute toxicities of four metals on the early life stages of the crab Chasmagnathus granulata from Bahía Blanca estuary, Argentina. Ecotoxicol. Environ. Saf., 65: 209-217, 2006

FIELD C.D. Impact of expected climate change on mangroves. Hydrobiologia, 295(1): 75-81, 1995

GARCÍA-GUERRERO M.; HENDRICKX M.E. Embryology of decapod crustaceans III: Embryonic development of Eurypanopeus canalensis Abele \& Kim, 1989, and Panopeus chilensis H. Milne Edwards \& Lucas, 1844 (Decapoda, Brachyura, Panopeidae). Belg. J. Zool., 136(2): 249-253, 2006

GIMÉNEZ L.; ANGER K. Relationships among salinity, egg size, embryonic development and larval biomass in the estuarine crab
Chasmagnathus granulata Dana, 1851. J. Exp. Mar. Biol. Ecol., 260(2): 241-257, 2001

HAILS A.J.; YAZIZ S. Abundance, breeding and growth of ocypodid crab Dotilla myctiroides (Milne-Edwards) on a West Malaysian beach. Estuar. Coast. Shelf. Sci., 15(2): 229-239, 1982

HATTORI G.Y.; PINHEIRO M.A.A. Fertilidade do caranguejo de mangue Ucides cordatus (Linnaeus) (Crustacea, Brachyura, Ocypodidae), em Iguape (São Paulo, Brasil).

Rev. Bras. Zool., 20(2): 309-313, 2003

JAMOVI. The jamovi project (Version 1.2) [Computer Software]. Retrieved from https://www.jamovi.org. 2020.

JOÃO M.C.A.; PINHEIRO M.A.A. Reproductive potential of Ucides cordatus (Linnaeus, 1763) (Decapoda: Brachyura: Ocypodidae) from two mangrove areas subject to different levels of contaminants. J. Crustac. Biol., 39(1): 74-81, 2018

KABATA-PENDIAS A. (ed.) Trace Elements in Soils and Plants. CRC Press, New York, 548 p. 2010

KJERFVE B.; RIBEIRO C.A.; DIAS G.T.M.; FILIPPO A.; QUARESMA V.S. Oceanographic characteristics of na impacted coastal bay: Baía de Guanabara, Rio de Janeiro, Brazil. Cont. Shelf. Res., 17(13): 1609-1643, 1997

LACERDA L.D.; MARTINELLI L.A; REZENDE C.E.; MOZETO A.A.; OVALLE A.R.; VICTORIA R.A.; SILVA C.A.R. The fate of trace metals in suspended matter in a mangrove creek during a tidal cycle. Sci. Total. Environ., 75(2-3): 169-180, 1988

LAVRADAS R.T.; HAUSER-DAVIS R.A.; LAVANDIER R.C.; ROCHA R.C.C.; SAINT' PIERRE T.D.; SEIXAS T.; KEHRIG H.A.; MOREIRA I. Metal, metallothionein and glutathione levels in blue crab (Callinectes sp.) specimens from southeastern Brazil. Ecotoxicol. Environ. Saf., 107: 55-60, 2014 LITULO C.; MAHANJANE Y.; MANTELATTO F.L.M. Population biology and breeding period of the sand-bubbler crab Dotilla fenestrata (Brachyura: Ocypodidae) from Southern Mozambique. Aquat. Ecol., 39(3): 305-313, 2005

LÓPEZ GRECO L.S.; RODRÍGUEZ L.M.; HERNÁNDEZ G.; BOLAÑOS J. Effects of copper on hatching of larvae and prezoea survival of Petrolisthes galathinus 
(Porcellanidae): Assays with ovigerous females and isolated eggs. Environ. Res., 90(1): 40-46, 2002

LYLA S.; KHAN A. Larval development of hermit crab Clibanarius longitarsus: Synergistic effect of heavy metals. Biologia, 65(4): 714-719, 2010

MACHADO W.; GUEIROS B.B.; LISBOAFILHO S.D.E; LACERDA L.D.. Trace metals in mangrove seedlings: role of iron plaque formation. Wetlands. Ecol. Manage., 13: 199-206, 2005

MACHADO W.; SILVA-FILHO E.V.; OLIVEIRA R.R.; LACERDA L.D. Trace metal retention in mangrove ecosystems in Guanabara bay, SE Brazil. Mar. Pollut. Bull., 44: 1277-1280, 2002

MELO G.V.; BAPTISTA NETO J.A.; MALM O.; SANTOS FERNANDEZ M.A.; PATCHINEELAM S.M. Composition and behaviour of heavy metals in suspended sediments in a tropical estuarine system. Environ. Earth Sci., 73: 1331-1344, 2014

MENDOZA-CARRANZA M.; SEPÚLVEDALOZADA A.; DIAS-FERREIRA C.; GEISSEN V. Distribution and bioconcentration of heavy metals in a tropical aquatic food web: A case study of a tropical estuarine lagoon in SE Mexico. Environ. Pollut., 210: 155-165, 2016

MENEGUELLI-SOUZA A.C.; PESTANA I.A.; AZEVEDO L.S.; DE ALMEIDA M.G.; DE SOUZA C.M.M. Arsenic in the lower drainage basin of the Paraíba do Sul River (Southeast Brazil): dynamics between the water column and sediment. Environ. Monit. Assess., 193(2): 57, 2021

MIGUENS F.C.; OLIVEIRA M.L.; FERREIRA A.O.; BARBOSA L.R.; MELO E.J.T.; CARVALHO C.E.V. 201Structural and elemental analysis of bottom sediments from the Paraíba do Sul River (SE, Brazil) by analytical microscopy. J. S. Am. Earth Sci., 66:82-96, 2016

MOLISANI M.M.; OVALLE A.R.C.; REZENDE C.E.; SALOMÃO M.S.M.B.; LACERDA L.D.; CARVALHO C.E.V. Heavy metals in sediments of the lower Paraíba do Sul River and estuary - RJ Brazil.

Bull. Environ. Contam. Toxicol. 63(5): 682690, 1999

MOLISANI M.M.; SALOMÃO M.S.MB.; OVALLE, A.R.C. Partitioning of metals in sediments from the lower Paraíba do Sul River, SE, Brazil. Geochim. Bras., 19(1): 4859, 2005

MONTEIRO F. F., CORDEIRO R.C., SANTELLI, R.E., MACHADO W., EVANGELISTA H., VILLAR L.S., VIANA L.C.A., BIDONE E.D. Sedimentary geochemical record of historical anthropogenic activities affecting Guanabara Bay (Brazil) environmental quality. Environ. Earth Sci., 65: 1661-1669, 2012

MORGAN S.G. Predation by planktonic and benthic invertebrates in larvae of estuarine crabs. J. Exp. Mar. Biol. Ecol. 163(1): 91110, 1992

MORGAN S.G. The timing of larval release. In: McEdward L.R. Marine Invertebrate Larvae. CRC Press, Boca Raton, p.: 157-191, 1995.

MORTIMER M.R. \& MILLER G.J. Susceptibility of larval and juvenile instars of the sand crab, Portunus pelagicus (L.), to sea water contaminated by chromium, nickel or copper. Aust. J. Mar. Freshwater Res., 45: 1107-1121, 1994

NORDHAUS I.; WOLFF M. Feeding ecology of the mangrove crab Ucides cordatus (Ocypodidae): food choice, food quality and assimilation efficiency. Mar. Biol., 151(5): 1665-1681, 2007

PANDIAN T. Changes in chemical composition and caloric content of developing eggs of the shrimp Crangon crangon. Helgol. wiss. Meeresunters., 16: 216-224, 1967

PANDIAN T. Ecophysiological studies on the developing eggs and embryos of the European lobster Homarus gammarus. Mar. Biol. 7: 249-254, 1970

PASUPATHI K.; KANNUPANDI T. Effect of the heavy metal zinc on larval stages of the mangrove grapsid crab Sesarma pictum De Haan. Ind. J. Inv. Zool. \& Aquat. Biol. 1: 5357, 1989

PETERSEN S.; ANGER K. Chemical and physiological changes during the embryonic development of the spider crab, Hyas araneus L. (Decapoda: Majidae). Comp. Biochem. Physiol. B, 117(2): 299-306, 1997

PINHEIRO M.A.A.; HATTORI G.Y. Embryology of the mangrove crab Ucides cordatus (Brachyura, Ocypodidae). J. Crust. Biol., 23(3): 729-737, 2003

PINHEIRO M.A.A.; RODRIGUES A.M.T. Crustáceos sobre-explotados e o Plano 
Nacional de Gestão dos caranguejos uçá (Ucides cordatus), guaiamú (Cardisoma guanhumi) e do siri-azul (Callinectes sapidus): uma estratégia para evitar que passem ao "status" de ameaçados de extinção. Rev. CEPSUL - Biodivers. Conserv. Mar., 2(1): 50-57, 2011

PINHEIRO M.A.A.; BAVELONI M.D.; TERCEIRO O.S.L. Fecundity of the mangrove crab Ucides cordatus (Linnaeus, 1763) (Brachyura, Ocypodidae). Invertebr. Reprod. Dev., 43(1): 19-26, 2003

PINHEIRO M.A.A.; FISCARELLI A.G.; HATTORI G.Y. Growth of the mangrove crab Ucides cordatus (Crustacea, Brachyura, Ocypodidae). J. Crustac. Biol. 25(2): 293301, 2005

PINHEIRO M.A.A.; GANDARA E SILVA P.P.; DUARTE L.F.A.; ALMEIDA A.A.; ZANOTTO F.P. Accumulation of six metals in the mangrove crab Ucides cordatus (Crustacea: Ucididae) and its food source, the red mangrove Rhizophora mangle (Angiosperma: Rhizophoraceae). Ecotoxicol. Environ. Saf., 81: 114-121, 2012

RAINBOW P.S.; FURNESS R.W. Heavy Metals in the Marine Environment. In: Furness, R. (ed.). Heavy Metals in the Marine Environment. CRC Press, Boca Raton, p.: 14, 2018

RAINBOW P.S. Trace metal bioaccumulation: models, metabolic availability and toxicity. Estuar. Coast. Shelf. Sci., 21: 669-686, 2007 RAMOS E SILVA C.A.; SILVA A.P.; OLIVEIRA S.R. Concentration, stock and transport rate of heavy metals in a tropical red mangrove, Natal, Brazil. Mar. Chem., 99(14): 2-11, 2006

RODRÍGUEZ E.M.; MEDESANI D. Pathological lesions in larvae hatched from ovigerous females of Chasmagnathus granulata (Decapoda, Brachyura) exposed to cadmium. Experientia, 50(10): 975-977, 1994
SCHWAMBORN R.; SILVA T.A.; SILVA A.P.; EKAU W.; SAINT-PAUL U. Distribution and dispersal of decapod crustacean larvae and other zooplankton in the Itamaracá estuarine system, Brazil. Trop. Oceanogr., 29(1): 1-13, 2001

SILVA B.M.S.; MORALES G.P.; GUTJAHR A.L.N.; FAIAL K.C.F.; CARNEIRO B.S. Bioaccumulation of trace elements in the crab Ucides cordatus (Linnaeus, 1763) from the macrotidal mangrove coast region of the Brazilian Amazon. Environ. Monit. Assess. 190: 214, 2018

SIMONETTI P.; BOTTÉ S.E.; FIORI S.M.; MARCOVECCHIO J.E. Heavy-metal concentrations in soft tissues of the burrowing crab Neohelice granulata in Bahía Blanca Estuary, Argentina. Arch Environ Contam Toxicol 62(2): 243-253, 2012

SOARES-GOMES A.; GAMA B.A.P.; BAPTISTA NETO J.A.; FREIRE D. G.; MACHADO W.; BERNARDES M.C.; COUTINHO R.; THOMPSON F.L.; PEREIRA R.C. An environmental overview of Guanabara Bay, Rio de Janeiro. Reg. Stud. Mar. Sci., 8(2): 319-330, 2016

TSUI M.T.; WANG W.X. Biokinetics and tolerance development of toxic metals in Daphnia magna. Environ. Toxicol. Chem., 26(5):1023-1032, 2017

VITALE A.M.; MONSERRAT J.M.; CASTILHO P.; RODRIGUEZ E.M. Inhibitory effects of cadmium on carbonic anhydrase activity and ionic regulation of the estuarine crab Chasmagnathus granulata (Decapoda, Grapsidae). Comp. Biochem. Phys. A, 122C(1): 121-129, 1999

WANG W.X. Interactions of trace metals and different marine food chains. Mar. Ecol. Prog. Ser., 243: 295-309, 2002

WENG N.; WANG W. Dynamics of maternally transferred trace elements in oyster larvae and latent growth effects. Sci. Rep., 7: 3580, 2017 